Journal homepage:http://www.interscience.org.uk

DOI:10.18535/ijahm/v7i4.14

Impact Factor: 4.415

\title{
Conceptual Study on the Role of Virecana Karma in Management of Tamaka Shwasa
}

\author{
${ }^{1}$ Dr. Bhattarai Amrita , ${ }^{2}$ Bhusal Nirmal, ${ }^{3}$ Mangal Gopesh , ${ }^{4}$ Dr. Gunjan Garg \\ ${ }^{1}$ MD Scholar, Department of Panchakarma, NIA, Jaipur, India \\ ${ }^{2} \mathrm{PhD}$ Scholar, Department of Panchakarma, NIA, Jaipur, India. \\ ${ }^{3}$ Assistant Professor and Head I/C, Department of Panchakarma, NIA, Jaipur, India. \\ ${ }^{4}$ Associate Professor, MJF Ayurveda College, Jaipur, India \\ Corresponding Author: Dr. Amrita Bhattarai
}

MD Scholar, Department of Panchakarma, National Institute of Ayurveda Jaipur, India.

\begin{abstract}
Tamaka Shvasa is one of the five types of Shvasaroga. Tamaka Shvasa is a "Swantartra"Vyadhihaving its own etiology, pathologenesis and management.The cardinal symptoms of Tamaka Shvasa includes Shvasa Krichhrata (dyspnoea) $)^{l}$ Kasa(cough), Pinasa(rhinitis), Ghurghurukam, Parshvashula .According to Ayurveda Shvasaroga is a Kapha Vata Pradhana disease which originated from Pittasthana. Whenever there is obstruction of Pranavayu by Kapha Dosha, the vitiated Vayu gets Pratiloma Gati (reverse movement) to produce Shvasa Roga. Asthma is the chronic inflammatory disorder of the airway associated with increased hyper responsiveness, recurrent episode of wheezing shortness of breath, chest tightness and coughing particularly at night and early morning. The global prevalence of asthma is more than 300 million individuals and about a tenth of those are living in India. Acharaya Caraka and Vagbhata have described Virechana Karma in the management of Shvasa Roga. In Tamaka Shvasa, Kapha obstructs the passage of Vayu, the obstructed Vayu take the Pratiloma Gati. Virecana drugs having the quality of Vatanulomana, Usnaguna, Kaphavataghna property may be more beneficial in the condition of Shvasa. Virecana removes mainly Kapha and Pitta Dosha and makes Vata in Anuloma Gati. Thus this conceptual study was under taken to study the concepts of Tamaka Shvasa and role of Virechana Karmain Tamaka Shvasa.
\end{abstract}

Key Words: Tamaka Shvasa, Shvasa,Virechana, Karma, Kapha Dosha.

\section{INTRODUCTION}

Tamaka Shvasa is mentioned as one of the variety among five types of Shvasa. Among them Kshudra Shvasa is present as symptom in most of the diseases \& it does not require any medication whereas Maha Shvasa, Urdhva Shvasa \& Chinna Shvasa are present in the terminal stages of various diseases. Tamaka Shvasa is a 'Swantartra' Vyadhi \& having its own etiology, pathologenesis \& management. It is mentioned as Yaapya Vyadhi i.e. chronic in nature having cardinal symptoms like Shvasakrichhratal, Ghurghurukam, Pinasa, Kasa, Parshvashula. According to Ayurveda Shvasa roga ${ }^{2}$ is a Kapha Vataja disease which is originated from Pittasthana. Whenever there is obstruction of Pranavayu by Kapha Dosha, the vitiated Vayu gets Pratilomagati(reverse movement) to produce Shvasa Roga. Asthma is defined as a chronic inflammatory disorder of the airways in which many cells play a role in particular mast cells, eosinophils \& Tlymphocytes ${ }^{3}$. The susceptible individuals experience the recurrent episodes of wheezing, breathlessness, chest tightness \& cough particularly at night or in the early morning, due to this inflammation. These symptoms are usually associated with wide spread but variable air flow limitation that is at least partly 


\section{Dr. Bhattarai Amrita ${ }^{1}$, International Journal of Ayurvedic\& Herbal Medicine 7(4) July.-Aug.2017 (2733-2739)}

reversible either spontaneously or with treatment. To a variety of stimuli, the associated airways responsiveness is increased due to inflammation. The burden of asthma is immense, with more than 300 million individuals currently suffering from asthma worldwide, about a tenth of those living in India.The prevalence of asthma has been estimated to range 3-38\% in children and 2-12\% in adults. ${ }^{4}$ Shodhana is given a due importance in Tamaka Shvasa. Among Shodhana, Vamana \& Virechana are indicated in Tamaka Shvasa. Tamaka Shavasa is manifested by aggravated Prana Vayu due to obstruction of Kapha. Virechana Karmawith drugs having Vata Kaphahara property is indicated in the management Tamaka Shvasa.

\section{AIMS AND OBJECTIVES}

1. To study in details about Tamaka Shvasa.

2. To study the role of Virechana Karma in Tamaka Shvasa.

3. To study the role of Virechana Karma in cardinal signs of Tamaka Shvasa.

\section{MATERIALS \& METHODS}

- Different references regarding Tamaka Shvasa and Virechana Karmawere collected from Bruhatrayi, Laghutrayi, various textbooks and previous studies and compilation done.

- Concept of Tamaka Shvasa and Virechana Karma in Tamaka Shvasawas studied.

- Collection of all the references was done and correlation between the data was done logically i.e by using Yukti Pramana (Logical inferences).

\section{DISEASE REVIEW}

\section{Nidana (Etiology)}

According to Acharaya Charaka, "A single etiological factor may produce a single disease or many factors together may produce single disease and "vice versa". This holds true in Tamaka Shvasa as one or more etiological factors are responsible in production of Tamaka Shvasa. In Ayurveda texts Nidanas of Tamaka Shvasa are not described separately, but the Nidana of Shvasaroga in general are given. Multi factorial causes are responsible for development of Tamaka Shvasa. Nidana of Tamaka Shvasa can be categorized mainly of two types: 1. Bahya (Extrinsic) - like Dhuma, Raja,Vata, etc. 2. Ahyanatra (Intrinsic) - Kapha \& Vata Dosha vitiation. The Bahya Nidana acts through following three factors: Asatmendriyartha Samyoga, Prajnaparadha, Parinama. For Shvasa Roga to occur, Asatmendriyartha Samyoga plays important role. Mainly Ghranendriya, Sparsanendriya and Rasanendriya and their Asatmyaartha Samyoga may precipitate TamakaShvasa. For example exposure of the Ghranendriya to pollens, dusts etc. may evoke an Asatmyaindriya Artha Samyoga. Prajnaparadha is a conscious or unconscious indulgence in harmful activities. It is again of two types. A. Saririkaprajnaparadha, eg. Excessive indulgence in sex, excessive working and other similar activities. B. Manasika Prajnaparadha are fear, sorrow, anger, greed, anxiety, excitement, pride etc. Parinama means Kala i.e. the effect of climatic condition. This is observed that paroxysmal attacks of Shvasaroga occur during specific times and seasons, such as, cloudy climates, winter,rainy season and at nights. Sometimes, Nidanarthakara Rogas are also important factor, i.e Tamaka Shvasa can be produced secondarily to some disease eg. Jwara, Kasa, Pandu, etc. Acharaya Vagbhata has clearly mentioned that the neglected cases of Kasa may lead to Shvasa.

As already stated before, the etiology of Shvasa may also be considered as the etiology of Tamaka Shvasa. And these etiological factors have been divided according to Ahara,Vihara and Nidanarthakara Roga. Ahara Nidana are Visamasana (irregular diet), Sitasana (cold food), Ruksana (fat free diet), Anasana (fast), Vistambhibhojana (slowly digested food),Adhyasana (frequent meals), Visa Sevana(toxins), Sitaambu (cold water) Dvandvalayoga (mutually antagonistic).Kapha Prapokapaahara like Masa (black gram),Nispava (beans), Pistabhojan (paste preparation) ,Pinyaka (tila paste) Anupapisita, Jalaja Mamsa (aquatic fish) 
,Guru Bhojan (heavy diet), AmaKshira (unboiled milk), Dadhi (curd), Abhisyandi Anna, Tila Taila, Slesmala Dravya, Saluka (lotus rhizome), Suddhiatiyoga (excessive purification), Kantapratighata (throat trauma),Urahpratighata (chest trauma).Regarding Nidana related to Vihara,Vataprakopaka Vihara includes Vata (wind), Rajas (Dust), Dhuma (Smoke), Vyayama (exercise),Sita Sthana Sevana (to reside in cold place) ,Sitaambu (Cold Water), Gramyasevana (over indulgence in sex), Atyapatarpana (malnutrition), Bharavahan (excessive weight lifting),Marmaghata (trauma over vital organ), Vega Vidharana (suppression of urges), Suddhiatiyoga (excessive purification),Urahpratighata (chest trauma),Kantapratighata (throat trauma), Jagarana, Karmahata(exhausted). While Kaphaprakopaka Vihara includes Divaswapna(day sleep) and Abhisyandyupacaras. Ayurvedaalso advocates about the Nidanarthakara Roga ${ }^{6}$ like Amapradosa, Apatarpana, Vibandha (constipation), Anaha (distension of abdomen) ,Dhatuksaya (emaciation ) , Pratisyaya (coryza), Chardi (vomiting), Jwara (fever),Atisara (diarrhoea),Daurbalya (weakness), Urahksata (Trauma in chest), Alasaka ( food materials remain undigested),Pandu roga (anaemia), Udavarta (reverse motion of natural urges), Visucika (Acute gastro enteritis), Raktapitta, Kasa (cough), as important causative factors for Tamaka Shvasa.Vyanjaka Hetu is stimulating, precipitating or aggravating cause. It is due to Vyanjaka Hetu that the aggravation of symptoms occurs in an already generated disease or these cause the precipitation of the samprapti (pathogenesis) of a disease. The prior knowledge of these Hetu are useful in preventing the actual formation of diseases by preventing such factors.This includes Sleshma Vardhaka things (Kapha increasing matters), Ambu (water), Seeta (cold), Megha (clouds).

\section{Purvarupa (Prodromal Symptoms)}

The Purvarupa ${ }^{7}$ mentioned by Acharyas in Brihat Trayi ${ }^{8}$ and in Madhava Nidhana are Adhmana (flatulence), Bhaktadvesa (aversion to food), Arati (restlessness), Vairasya (bad taste in mouth), Hridpeeda (pericardial pain), Parsvasula (pain in the side of chest), Pratilomatva (Short and shallow breathing), Anaha ${ }^{9}$,Sankhabheda (pin pricking sensation on temporal region) .

\section{Rupas ( Clinical Features/ Symptoms)}

The important symptoms of Tamaka Shvasa which are helpful in diagnosis are as follows: Ativativravega ${ }^{10}$ shvasa, Ghurghurkam, Kasa, Asinolabhatesaukhyam, Mhur-mhurshvasa, Lalatesweda, Meghambupragvatevridhi. The various Rupaas described in Brihattrayi are Griva-Parigraha Stambha (stiffness of the Neck), Siraha Parigraha-Stambha (stiffness of the head), Ghuraghurakam (wheezing), Ativativravega Pranapidaka Shvasa (having sever bouts of dyspnoea),Ativegata Pratamyati (blackouts due to frequent bouts of dyspnoes), Kasate Sanni Rudhyate- (inactive due to coughing),Kasa, Janya Pramoha (fainting while coughing), Slesmani Amuchuamana Bhrusham Dukhitaha (inability to expectorate, he feels greatly distressed), Slesmani Vimokshante Muhuratam Sukhum (after expectoration gets temporary relief), Kanthodhvansa (pain in the throat), Krichrat Bhasitam (difficulty in speaking), Anindra (insomnia), Asinolabhate Saukhyam (comfort in lying), Sayanaha Shvasa Piditaha (aggravated in lying posture), Parshva Shula (lateral chest pain), Ushnabhinandati (desires hotthings), Uchhritaksaha(eyes are elevated widely opened), Lalate Sweda (forehead sweating),Bhrusumartiman (severe pain),Visuskasyata (dryness of mouth), Vamathu (vomiting),Meghachhanna Shwasa Vridhi (aggravated by cloudy weather),Ambuna Vridhi (aggravated by rains), Pragvataihi Vridhi (aggragated by wind), Sitakale Vridhi (aggravated by cold weather), Trut (thirst), Prasvedaha (perspiration), Abala (weak), Annadwesha (aversion towards food), Vepathu (tremor), Mahataghosa Shvasa (having loud sound), Sakasa (accompanied with cough), Urah Pida (chest pain) ,Bhakta Dwesha (anorexia), Aruchi, Moha (fainting),Durdine Vridhi (dyspnoea especially during cloudy weather).

\section{Samprapti(Pathogenesis)}


Describing Samanya Samprapti Acharya Charaka describes, Vitiated Vata enters The Pranvaha Shrotas and aggravates the Urastha Kapha. This Vikruta Kapha obstructs the normal flow of Pranvayu \& produces five types of Shvasa \& Hikka which en dangers the life. Acharya Shushruta explains that the Prana Vayu when leaves its normal physiological functions and when interacts with the Kapha ${ }^{11}$ it moves with Pratiloma gati and leads to development of Shvasa roga. Regarding specific pathogenesis Acharya Charaka explains that when Kapha obstructs the flow of Prana Vayuin the Pranvaha Shrotas, Prana Vaya moves in Pratiloma Gati and surrounds the neck and head and causes excess secretion of Dusta Kapha which results Pinasa (Coryza). Due to this excessive mucus discharge in Pranvaha Shrotasand there is obstruction of Pranavayu which produces characteristic sound Ghurghurkam (wheezing). This situation is aggravated when there is congestion, Sotha (inflammation) or irritation. This further increases the secretion in the tracts which causes coughing and patient tries to expel the thick, sticky sputum. If he or she is unable to expectorate than the respiration rate increases and constriction of air tracts occurs. As a result the expiration becomes prolonged and the inspiration shortens. This condition causes Dyspnoea. Thus the exchange of Vishnupadamrutama (oxygen) is not proper. Due to which results in other systemic symptoms like pain giddiness, dryness of mouth, desire for hot objects and disturbed sleep.

\section{Chikitsa (Treatment)}

Overall management of Tamaka Shvasa can be divided into: Nidana Parivarjana (avoiding etiology), Shodhana ( bio-purification), Avastika Chikitsa \& Shamanoushadhi (oral medication). As Samana therapy the medicines and the dietetic regimen which controls the Kapha and Vata due to their Ushna Guna and are Vata-Anulomaka in action should be utilized in the treatment of Shvasa Roga. Acharya Charaka explains that the patient with Kapha ${ }^{12}$ and Vata dominance and of strong build should be given Samshodhana therapy i.e. Vamana \& Virechana. And according to Acharya Vagbhata, in Balavana (strong) and in Kaphadhika Karshana Chikitsa should be done, while in Durbala (weak), Bala (child) Brumhana Chikitsais recommended and in Vridha(old person) Shamana Chiktsa is adviced.

\section{VIRECHANA REVIEW}

Sodhana Karma is prerequisite in managing the condition of Tamaka Shvasa, particularly in patients with sufficient strength, because the disease is manifested by the aggravated Prana Vayu by the obstruction of Kapha $^{13}$. Virecana Karma is appropriate as the origin of the pathogenesis is said to be started from Pittasthana. And the aggravated Kapha and Vata are amenable to Virecana at the level of Adhoamasaya. Virechanais the prime treatment for Pitta Dosha \& also effectively manages the Kapha \& Vata Dosha. It pacifies the Pitta Dosha by Adhobhagharana. According to Ayurveda, Pitta is closely related with Agni, which is responsible for the digestive and metabolic processes in the body. So Virechanais an important measure of Panchkarma which is used for the treatment of Kayagni. So Virechana has its specific action on Pitta \& Kapha Dosha which are expelled from Amashya, Grahani \& Pakvasya through Adhomarga. Acharya Charaka defined Virechana ${ }^{14}$ as the process of eliminating of Dosha through the Adhobhaga (Anal route).While according to 'Gangadhara' elimination of Dosha in general is termed as Virechana. But in practical use Virechana is considered as the purification through anal route only. Detailed description of Virechana is present in all most all the Ayuveda text. The various references of Virechana in Ayurveda classics are, Charak Samhita Sutrasthan Chap.-1, 2, 4, 15, Chikitsasthana, Kalpsthana- Chap. 7th to 12th, Siddhisthana- Chap.1, 2, 6 Sushruta SamhitaSutrasthana- Chap 39, 41, 44, Chikitsasthana-33, 34, . Astangsamgraha Sutrasthana- Chapter 27. Astang Hridaya Sutrasthana- Chap.18, Kalpsthana Chap. 3,Sharangdhar Samhita Purva Khanda- Chapter4, Uttarkhanda- Chapter 4 Chakradatta Chapter-71 Bhav Prakash Purvakhand. 
Dr. Bhattarai Amrita ${ }^{1}$, International Journal of Ayurvedic\& Herbal Medicine 7(4) July.-Aug.2017 (2733-2739)

\section{Indication of Virechana}

1) As Dosha Pratyanika Chikitsa ${ }^{15}$,Virechana is indicated in conditions like excessive Pitta Dosha where Rakta is the Pradhana Dosha i.e. Kustha, Visarpa, Rakta Pitta, Gudapaka, Pitta- Kaphaja conditions like Adhoga Amla Pitta, Pitta invading the site of Kapha, Vayu located in Pakwashya. If Vayu in association with Pitta, it pervades the entire body.In the treatment of Vayu Mridu Virechana is indicated like Pakshaghata. Acharya Bhela has mentioned Virechana in 'Sannipata' condition also.

2) As Vyadhi Prtyanika Chikitsa,Pitta Sthana Gata Vyadhi like Shvasa diseases having deep seated pathology like Unmada, Apasmara ,diseases involving multiple Doshas and Dushyas needing Teekshna Shodhana like Garavisha, Krimi Kostha, Prameha etc. Disease in which Marga Virodha as a treatment is indicated like Urdwa, Rakta Pitta, Chhardi. In which Anulomana of Vayu is required like Udavarta, Udararoga, Yoni Vyapada.As both Dosha and Vyadhi Prtyanika Chikitsa disease dominated by Pitta like Kamala, Pandu.In diseases like Grahani where aggaravated Pitta itself hampers Agni. Diseases caused by Aam like Visuchika. In Astangasangraha Shodhana (Virechana) has been mentioned for the treatment of Sama Dosha, Sama Dushya.

\section{TAMKETU VIRECHANA ${ }^{16}$ :}

Acharyacharak has clearly mentioned about the indication of Virechana Karma in Tamaka Shvasa. And he further emphasizes that the Vatanulomana \& regular cleaning of the Srotas of the Vayu should be done. In classical Ayurveda texts Shvasa Roga is said to be originated from the Pittasthana and the site of its expression is Uraha Pradesh. The main Dosha involvement here is of Kapha \& Vata, and the Gati of Vata is Pratiloma. The Pratiloma Gatiof Vayu must be brought to Anulomana. The Pittasthana disturbance leads to indigestion \& production of Aama Dosha which is the cause of production of Vikrut Kapha Dosha. So it is important is to treat the root cause of Shvasa Roga i. e. Pittasthana. So this pathogenesis is broken by Kapha Vataghana and Ushnaguna Ausadha, drinks \& diet. And to achieve this, Virechan Karma is the process which does the Vataanulomna and is Kapha- Vataghana. Secondly, Dusti of Pitta Sthana is the root cause of this disease and for removal of this Dusta Pitta Virechan Karma is the best procedure. Virecana is very useful when it is combined with Vatahara and Kaphahara drugs ${ }^{12}$. The patient of Tamaka Shvasa is mostly weak and in chronic stage, Hridya as the Mula of Pranavaha Shrotas is also involved. In this condition Vamana is very difficult and complicated procedures \& the Virechana is easily done without threatening the life of the patient.

\section{DISCUSSION}

Ayurveda considers Shvasa Roga as disease of Pranavaha, Udakavaha and Annavaha Srotas. Acharya Charaka explains that when in the Pranvaha Shrotas, Kapha obstructs the flow of Prana Vayu, theVayu moves in Pratilomagati and surrounds the neck and head and causes excess secretion of Dusta Kapha which produces Pinasa (Coryza). Due to this excessive mucus discharge in Pranvaha Shrotas there is obstruction of Pranavayu \& which produces characteristic sound like Ghurghurkam (wheezing): Ativa Tivravega Shvasa etc. And the important symptoms of Tamaka Shvasa which are helpful in diagnosis are as follows: Ativativravega Shvasa, Ghurghurkam, Kasa, Asinolabhatesaukhyam, Mhur-mhurshvasa ,Lalatesweda ,Meghambupragvatevridhi.

Shvasa Roga originates from the Pittasthana and the site of its expression is Uraha Pradesh. Here Dosha involvement is of Kapha \& Vata. The Pratilomagati of Vayu must be brought to Anulomana. The Pittasthana disturbance leads to indigestion \& production of Aama Dosha which is the cause of production of Vikrut Kapha Dosha. So it is of prime importance to treat the root cause of Shvasa Roga i. e. Pittasthana. 
Dr. Bhattarai Amrita ${ }^{1}$, International Journal of Ayurvedic\& Herbal Medicine 7(4) July.-Aug.2017 (2733-2739)

Hence Virechana is the main treatment to eliminate the Dusta Pitta and also for Vata Anulaomana, property Virechana is equally effective and important.

\section{CONCLUSION}

Cardinal symptoms of Tamaka Shvasa can be managed with Vata and Kaphahara drugs used in Virechana Karma. Virechana Karma may be very effective and safe in the management of Tamaka Shvasa.

\section{REFRENCES}

1. Shastri Kashinath, Agnivesh's Charaka Samhita with Ayurveda-Dipika Commentary by Cakrapanidatta and with Vidyotini Hindi commentary, Varanasi, Chaukambha Sanskrit Academy,reprint edition,2012,part 2,chikitsa Sthana17/55-62,440,441.

2. Shastri Kashinath, Agnivesh's Charaka Samhita with Ayurveda-Dipika Commentary by Cakrapanidatta and with Vidyotini Hindi commentary, Varanasi, Chaukambha Sanskrit Academy, reprint edition,2012,part 2,chikitsa Sthana17/8,434.

3. Nicholas A.Boon et all, Davidson's Principles and Practice Of Medicine, Illustrated by Robert Britton, Boon, College, Walker, Hunter, Churchill Livingstone, Elsevier Limited, First Indian Reprint 2006,page no 670.

4. Koul PA, Patel D. Indian guidelines for asthma: Adherence is the key. Lung India [ serial online] 2015 [cited 2017 Jul 12]; 32, suppl S1:1-2

5. Shastri Kashinath, Agnivesh's Charaka Samhita with Ayurveda-Dipika Commentary by Cakrapanidatta and with Vidyotini Hindi commentary, Varanasi, Chaukambha Sanskrit Academy, reprint edition,2012,part I , Nidana Sthana 8/24,25.Page no 542.

6. Indu, Vrddha Vagbhata"s Astangasamgraha with the Sasilekha Sanskrit Commentary,Varanasi Chaukambha Sanskrit Series Office, Nidhana Sthana 4/1,Page 370.

7. Shastri Kashinath, Agnivesh's Charaka Samhita with Ayurveda-Dipika Commentary by Cakrapanidatta and with Vidyotini Hindi commentary, Varanasi, Chaukambha Sanskrit Academy, reprint edition,2012,part II,ChikitsaSthana 17/20, Page no 436.

8. Kabiraja Haranacandra Cakravati, Susruta's Susrutasamhita with Susrutartha Sandipana Bhasya Commentary, Varanasi, Chaukhamba Surbharati Prakashan, Volume 3,Uttaratantra,51/6, page 452.

9. Tripathi B,Shrimadvagbhata's Astanga Hrdayam with Nirmala Hindi Commentary Delhi, Chaukhamba Sanskrit Pratishthan, NidhanaSthana 4/6,page no 455.

10. Shastri Kashinath, Agnivesh's Charaka Samhita with Ayurveda-Dipika Commentary by Cakrapanidatta and with Vidyotini Hindi commentary, Varanasi, Chaukambha Sanskrit Academy, reprint edition,2012,Part II,ChikitsaSthana ,chapter 17.

11. Kabiraja Haranacandra Cakravati, Susruta's Susrutasamhita with Susrutartha Sandipana Bhasya Commentary,Varanasi,Chaukhamba Surbharati Prakashan,Volume 3,Uttaratantra,51/4,page 452.

12. Shastri Kashinath, Agnivesh's Charaka Samhita with Ayurveda-Dipika Commentary by Cakrapanidatta and with Vidyotini Hindi commentary, Varanasi, Chaukambha Sanskrit Academy, reprint edition,2012, Part II ChikitsaChikitsa,17/48,page no 439.

13. Tripathi B, Shrimadvagbhata's Astanga Hrdayam with Nirmala Hindi Commentary Delhi, Chaukhamba Sanskrit Pratishthan, NidanaSthana 4/3page no 454.

14. Shastri Kashinath, Agnivesh's Charaka Samhita with Ayurveda-Dipika Commentary by Cakrapanidatta and with Vidyotini Hindi commentary, Varanasi, Chaukambha Sanskrit Academy, reprint edition,2012,KalpaSthana,1/4.

15. Indu, Vrddha Vagbhata"s Astangasamgraha with the Sasilekha Sanskrit Commentary,Varanasi Chaukambha Sanskrit Series Office, Nidhana Sthana 27/4,Page 203.

16. Tripathi B, Shrimadvagbhata's Astanga Hrdayam with Nirmala Hindi Commentary Delhi, Chaukhamba Sanskrit Pratishthan ,SutraSthana 18/3 page no 219. 